\title{
Eläimet Veikko Huovisen tuotannossa
}

\section{Luokittelusta eläinsuhteen ilmenemiseen}

Eläinaiheiset lyhytkertomukset muodostavat selvän kokonaisuuden Veikko Huovisen tuotannossa, mutta kirjailija kuvasi eläimiä ja hyödynsi eläinkuvastoa myös romaaneissaan. Artikkeli tarkastelee Huovisen "eläintekstejä" ja luo aiempaan eläinesitysten tutkimukseen nojaten luokittelun, joka osoittaa kirjailijan käsitelleen eläinkuntaa ja siihen liittyviä asetelmia harvinaisen monipuolisesti. Vaikka eläinasetelmia hyödynnetään toisinaan satiirin ja komiikan välineinä, tuotantoon kuuluu myös eläinten kokemusta hienovaraisesti esittäviä ja eläinten oikeuksien puolesta puhuvia teoksia.

Muistelmateoksessaan Muina miehinä Veikko Huovinen (1927-2009) nostaa eläinkertomuksen "lyhyiden erikoistensa" itsenäiseksi alalajiksi ja korjaa samalla niiden pelkästään satiirisiin, parodisiin tai humoristisiin puoliin nojaavaa lajittelua (200I, 229).' Eläinaiheiset lyhytkertomukset muodostavat selkeimmän eläinaiheisen kokonaisuuden kirjailijan tuotannossa, mutta tietoisuus eläimistä läpäisee koko tuotannon esikoisromaanin Havukka-ahon ajattelija (1952) aloittavasta Mikki-kissan toimien tarkastelusta vuosituhannen vaihteen uusiin "eläinaiheisiin erikoisiin". ${ }^{2}$ Huovisen tekstuaaliseen eläinmaailmaan kuuluvat yhtä lailla mielikuvitukselliset hybridit, lemmikit, tuotantoeläimet kuin villieläimet. Hän on myös suoraan kiinnittänyt huomioita eläinten huonoon kohteluun kirjoituksessaan "Ihminen ja eläin" (1963).

Laajasti ottaen eläimet kuuluvat aihepiiriin luonto, ja tätä Huovisen tuotannon osa-aluetta on jo ennestään pohdittu muun muassa ympäristösuuntautuneen kirjallisuudentutkimuksen näkökulmasta (Lahtinen 2008). Koska eläimet ovat niin selkeä osa Huovisen tuotantoa, ei niitä ole voitu sivuuttaa myöskään sitä läpikäyvässä tutkimuksessa. Esimerkiksi Tero Liukkonen on huomioinut eläimet Huovisen koko tuotantoa tarkastelevassa tutkimuksessaan Veikko Huovinen. Kertoja, veitikka, toisinajattelija (1997). Hänen konkreettisin tuloksensa on, että eläimillä on Huovisen tuotannossa osansa etenkin koomisen esille tuomisessa (mt. 54-55). Liukkonen myös huomaa Huovisen kiinnostuksen faabeliin ja esittää kirjailijan varioineen lajia (mt. II6-I20, I30, I35). Muu aiempi tutkimus on niin ikään kiinnittänyt kattavasti huomiota teosten huumoriin ja satiirisuuteen (Rajala 2012, Riikonen 2012, Seppälä 1992). Olen myös aiemmassa artikkelissani käsitellyt eläinten asemaa Huovisen tuotannossa satiirin ja huumorin puolia painottaen (Kantola 2013).

\footnotetext{
${ }^{1}$ Kirjailija ei tässä yhteydessä tarkenna käsitystään faabelilajista.

${ }^{2}$ Viittaan tässä valikoimaan Porsaan paperit (1999), johon on koottu Huovisen "eläinaiheisia erikoisia". Siihen sisältyy uutena materiaalina eläinten haastattelujen kokonaisuus (1999, 9-44). Muistelmateos Muina miehinä osoittaa kirjailijan itse valinneen kokonaisuuden (2001, 339).
} 
Tarkastelen tässä artikkelissa Veikko Huovisen eläintekstejä hänen koko tuotantonsa pohjalta. ${ }^{3}$ Pyrkimyksenäni on tuoda esiin Huovisen eläimiin keskittyneiden tekstien lukuisuus sekä niiden monipuolisuus eläimen tai tämän kokemuksen representoinnissa. Luon tekstien pohjalta luokittelun, joka kuvaa niiden ilmentämää suhdetta eläimeen. Suhteutan Huovisen tuotannon pohjalta hahmottuvaa luokitteluani jo olemassa olevien eläinesitysten tai eläimen kokemusten kuvausten luokitteluihin ja otan lopuksi kantaa kysymykseen, miksi ne eivät tarjoa kaikilta osin riittäviä puitteita Huovisen tuotannosta esiin nousevan eläinhuomion kategoriointiin. ${ }^{4}$

\section{Eläinesitysten luokittelut}

Kirjallisuudentutkija John Simons on pohtinut teoksessaan Animal Rights and the Literary Representation (2002) kirjallisuuden hyödyntämiä tulokulmia eläimen esittämiseen. Hän kutsuu näitä toistuvia asetelmia troopeiksi (mt. 176). ${ }^{5}$ Simonsin erityisyytenä on hänen eläineettinen lähtökohtansa: erittelyn ohessa hän pohtii kunkin tulokulman eläineettisiä ulottuvuuksia. Simonsin mukaan kaikki kirjallisuuden eläinrepresentaatiot ovat jossain mielessä antropomorfismin eli inhimillistämisen tai ihmisenkaltaistamisen läpitunkemia sen vuoksi, että ne aina välittyvät ihmismielen ja siten inhimillistävän toiminnan kautta. Antropomorfismi (merkityksessä eläimen esittäminen ihmisen tapaan) on kuitenkin myös yksi toistuva eläinten kuvaamisen ote tai "trooppi". Simons näkee antropomorfismin ilmenemisessä aste-eroja ja arvottaa niitä eläinoikeudellisesta näkökulmasta. Antropomorfismi voi hänen mukaansa näyttäytyä kirjallisuudessa faabelina tai triviaalina, heikkona tai vahvana muotona ( $\mathrm{mt}$. I I8).

Muita Simonsin nimeämiä eläinten esittämisen strategioita ovat eläinten symbolinen käyttö ja (muodon)muutoskertomukset (narratives of transformation). Symbolinen käyttö on kaikkein yleisin kirjallisuudessa, varsinkin runoudessa, käytetty eläinten esittämisen tapa. Simons ei ota kantaa siihen, että hänen antropomorfismin yhteydessä käsittelemänsä faabeli eli eläinallegoria rakentuu symbolisen esittämisen varaan. Sen sijaan hän korostaa, etteivät eläimet ole vain merkkejä paperilla vaan eläviä olentoja, jotka ansaitsevat syvällisemmän käsittelyn myös kirjallisuudessa. Transformaatiokertomuksista Simons löytää monia alailmentymiä, joista

\footnotetext{
${ }^{3}$ Käytän artikkelissa pääsääntöisesti käsitettä "eläin" "toislajisen", "vieraslajisen" tai "eiinhimillisen" eläimen sijaan. Jaan kuitenkin näihin termeihin sisäänkirjoitetun ajatuksen siitä, että ihminen on eläin muiden joukossa ja ettei muiden eläinten erityisyyttä sinänsä voi niputtaa yhden termin alle (vrt. Aaltola 20I2, 25).

${ }^{4}$ Olen esitellyt luokitteluni ensimmäisen kerran vuoden 2013 Eläintutkimuspäivillä, ja haluan erityisesti kiittää Yhteiskunnallisen ja kulttuurisen eläintutkimusseuran puheenjohtajaa Jouni Teittistä huomioni kiinnittämisestä John Simonsin teokseen.

${ }^{5}$ Vrt. troopin käyttötapa Greg Garrardin teoksessa Ecocriticism (20I2, 8). Garrard pitää "eläintä" yhtenä kulttuurisena trooppina (20I2, I53). Hän laatii myös oman eläinten kulttuurisen esittämisen typologiansa, joka jakautuu kaltaisuuden ja erojen (LikenessOtherness) mukaan kahteen lähtökohtaan (ks. tarkemmin mt., I54).
} 
osa on enemmän tai vähemmän tulkinnallisia, etäällä fyysisestä muodonmuutoksesta $(2002,140-172) .{ }^{6}$ Simons toteaa analyysiensa alussa, että kaikki kirjallisuuden eläinesitykset ovat variaatioita niistä kolmesta tulokulmasta, jotka hän kirjassaan esittää (mt., 85).

Narratologi David Herman on puolestaan pohtinut eläinkokemuksen esittämisen strategioita sarjakuva-aiheisessa artikkelissaan, jossa hän suhteuttaa strategiat elinympäristön esittämiseen ja asettaa ne neliportaiselle jatkumolle hienosyisestä karkeasyiseen (2012, 97-99). Hermanin jaottelu ei koske ainoastaan sarjakuvaa, eikä hän jaottelussaan ota kantaa Simonsin näkemyksiin, vaikka niissä lähtökohtien eroista huolimatta onkin kaltaisuuksia. Hermanin jaottelun neljä kulmakiveä ovat eläinallegoria, antropomorfinen projektio, zoomorfinen projektio sekä baltiansaksalaisen biologin ja filosofin Jacob von Uexküllin ajatuksista ammentava "Umwelt exploration" eli elinympäristön tutkiminen. Uexküll loi käsitteen "Umwelt" kuvamaan eläimen kokemusta omasta elinympäristöstään teoksessaan Umwelt und Innenwelt der Tiere (1909). Eläinallegoria, joka vastaa osin Simonsin faabelipohdintoja, sijoittuu Hermanin esittämän jatkumon karkeasyisimpään laitaan. Siinä eläimen kokemus on häivytetty kokonaan ja eläimet ovat ikään kuin ihmisten sijaisia. Antropomorfinen projektio on eläinallegoriaan nähden askel kohti hienosyisempää eläinkokemuksen kuvausta, mutta vain näennäisesti, sillä siinä ihmisten vaikuttimet ja käytännöt toimivat lähtökohtina eiinhimillisten eläinten käytöksen tulkinnassa. Hermanin zoomorfisessa projektiossa eläinten kokemukset ja kyvyt on niin ikään käännetty inhimilliseen suuntaan, muttei niinkään selityksen vaan vertailun vuoksi. Kerronnallisena strategiana zoomorfinen projektio näyttää, millaista olisi, jos ihmishahmot saisivat eläinten ominaisuuksia. (Herman 2012, 97-99.)

Myös Simons suo laajan huomion zoomorfiselle esittämiselle transformaatiota käsittelevässä luvussaan, vaikka hän ei käytä kyseistä termiä. Kategoriat eroavat toisistaan sikäli, että Simons (2002, I I6-139) näyttää eläinten ja ihmisten kokemusten vertailun heräävän jo antropomorfisen esittämisen kautta. Sen sijaan Hermanin jaottelun hienosyisin eläinkokemuksen esittämisen muoto ja hänen sarjakuvanalyysinsä ydin, Umwelt exploration eli elinympäristön tutkailu, jossa ollaan mahdollisimman etäällä inmiskeskeisestä eläinkokemuksen kuvauksesta, ei suoraan sisälly Simonsin tulokulmiin, mutta sen voidaan ajatella edustavan vastausta niihin eläinoikeudellisiin pyrkimyksiin, joita hän muiden esitysstrategioiden yhteydessä tuo esiin. Siinä on kaikkein vähiten ei-inhimillisen kokemuksen kääntämistä ihmiskokemuksen kautta. Sen sijaan painopiste on elinpiiriinsä osallistuvien eläinten ilmiöllisissä kokemuksissa. Termiä Umwelt Herman $(2012,99)$ käyttää Jakob von Uexküllin tarkoittamassa mielessä: se viittaa eläimen elinympäristöön sellaisena kuin tämä sen kokee eli maailmaan sellaisena kuin se näyttäytyy eläimelle sen aistimusvalikoiman pohjalta.

${ }^{6}$ Simonsin tavoite ei näyttäisi niinkään olevan transformaation käsitteen kehittely analyyttiseksi työkaluksi, vaan pikemminkin hän pyrkii havainnollistamaan laajasti ymmärretyn transformaation avulla ihmisen ja eläimen välisen dikotomian kaunokirjallisia ylityksiä $(2002,140)$. 
Seuraavassa esittelemäni Huovisen eläintekstien luokittelu pohjautuu havainnolle kirjailijan eläinten tai eläimen aseman kuvaamisen monipuolisuudesta. Luokittelun aineistona ovat sellaiset kirjailijan tekstit, joissa eläin tai siihen liittyvä asetelma on etualalla. Näitä kutsun - määritelmää paikoin venyttäen - yleisnimityksellä "eläinteksti" tai "eläinkertomus". Yksi luokka ei välttämättä kuvaa yksittäistä tekstiä eläinasian kannalta poissulkevasti, vaan useampi luokka voi toteutua yhdessä tekstissä. Artikkelin loppuun sijoitettu taulukko havainnollistaa tätä. Vaikka luokittelu pohjautuu yhden kirjailijan tuotantoon, voi sen kautta tarkastella myös muun kirjallisuuden eläinesiintymiä.

Luokitteluni lähtökohtana on ihmisen ja eläimen välinen suhde sellaisena kuin se näyttäytyy eläimen esittämisen strategiana. Jaan Huovisen eläintekstit ensinnäkin ensisijaisiin ja toissijaisiin sen mukaan, missä asemassa eläin tekstissä on. Ensisijaiset eläintekstit jakautuvat alakategorioihin, ja niissä kuvataan eläintä tai sen kokemusta tai jäljitellään sitä. Toissijaisessa eläintekstissä viitataan eläimeen yleisemmällä tasolla siten, että ihminen puhuu sen asemesta. ${ }^{7}$ Ensisijaisiin eläinteksteihin lukeutuvat tekstit, joissa eläin saa ihmisen ominaisuuksia ${ }^{8}$ (lyhenne EIO) tai joissa ihminen saa eläimen ominaisuuksia (lyhenne IEO) tai joissa eläin esitetään eläimenä (lyhenne $\mathrm{EE}$ ); nämä muodostavat kukin oman kategoriansa. Toissijaisia eläintekstejä ovat leimallisesti sellaiset tekstit, joissa ihminen toimii eläimen äänitorvena ja joissa tuodaan esiin eläinten oikeuksia (lyhyenne IE). Näin ollen Huovisen eläintekstien pohjalta hahmottuu neliluokkainen eläintekstien jaottelu.

Seuraavassa tarkastelen, miten ihmisen suhde eläimeen hahmottuu kunkin kategorian kautta, samoin kuin tuon esille muita asetelmien herättämiä eläimen ja ihmisen suhteen kysymyksiä. Aloitan transformaatioita kuvaavista luokista ja pohdin niitä pidempään, sillä ne muodostavat Huovisen tuotannon laajimman eläintekstien joukon. Sen jälkeen otan esille luokitteluni kaksi jäljelle jäävää luokkaa, joilla on yhtymäkohtansa eroavista lähtökohdista (ensisijainen / toissijainen) huolimatta. Tämän artikkelin puitteissa ei ole mahdollista läpikäydä seikkaperäisesti kaikkia Huovisen tuotannon eläimiin tai eläimellisiin asetelmiin liittyviä kertomuksia, mutta ne on pyritty kirjaamaan artikkelin lopun luokittelua kuvaavaan taulukkoon. Suhteutan näkemyksiäni Simonsin ja Hermanin edellä esiteltyihin jaotteluihin soveltuvin osin osoittaen samalla niiden kaltaisuuden tai eron suhteessa omaan luokitteluuni. ${ }^{9}$

\footnotetext{
${ }^{7}$ Olen Simonsin kanssa yhtä mieltä siitä, että eläinten esittäminen kirjallisuudessa on aina jollain tavoin antropomorfismin läpitunkemaa - ovathan kertomukset inhimillisiä, ja siksi eläimiä esitettäessä aina puhutaan "niiden sijaan". Tässä ajetaan kuitenkin takaa konkreettisempaa "puolesta puhumista".

${ }^{8}$ Käsitykseni ominaisuudesta vastaa tässä sanakirjamääritelmää: sillä tarkoitetaan jotakin jollekin oliolle ominaista, siihen (sen olemukseen, luonteeseen, rakenteeseen) kuuluvaa seikkaa tai piirrettä (Nykysuomen sanakirja. Osa IV: O-R).

${ }^{9}$ Herman esittelee neliportaisen jatkumonsa "zoonarratologiaa" kehittelevässä artikkelissaan lyhyesti, kun taas Simonsin teoksessa pohditaan laajemmin tämän artikkelin tavoitteiden kannalta olennaisia kysymyksiä. Hermanin jaottelun eläinten kokemuksen esittämisen hienosyisin muoto - Umwelt exploration - on kuitenkin merkittävä lisä eläin-
} 


\section{Eläin saa ihmisen ominaisuuksia}

Faabeli on eläinkertomus, jossa eläimet toimivat inmisten sijaisina. Faabelin ytimessä on siten inhimillisen käyttäytymisen ruodinta, ja siihen sisältyvä moraalinen opetus koskee ensijaisesti ihmisyhteisöä. John Simonsin mukaan faabeli ei ole eläinkysymyksen kannalta kiinnostava laji (2002, I 19). Huovisen eläinteksteistä kirjoittaneet ovat olleet yhtä mieltä niiden allegorisesta luonteesta, ja tämä tulkintamahdollisuus niissä on, mutta hieman Franz Kafkan eläinkertomusten tapaan pelkkä allegorinen tulkinta ei tunnu riittävän. Naama Harelin (2009) mukaan faabelit ilmaisevat harvoin suorasanaisesti mitään eläinten kohtelun kannalta suopeaa, mutta tästä huolimatta niitä voidaan lukea myös siten, että tekstin opetus lavenee myös eläimiä koskevaksi. Näkemys sopii niihin Huovisen eläinkertomuksiin, joissa allegorisuus on vahvimmillaan. Perinteiseen faabelilajiin Huovisen eläintekstit eivät näyttäisi sopivan sen vuoksi, että niissä nimenomaan käsitellään eläinten hyvinvointiin ja kohteluun liittyviä konkreettisia ja moraalisia kysymyksiä. Näin ollen niissä suhteellisen suoraan kehotetaan ottamaan eläimet huomioon myös kuvitelman ulkopuolisessa todellisuudessa.

Kertomukset, joissa eläimet saavat ihmisen ominaisuuksia, muodostavat suositun eläinkertomusten lajin. Faabeli eli eläinallegoria edustaa tämän luokan yhtä ääripäätä eli sellaista kertomusta, jossa inhimilliset ominaisuudet ovat syrjäyttäneet eläimelliset. ${ }^{10}$ Vaikka varsinaiset muodonmuutoskertomukset eläimestä ihmiseksi tai ihmisestä eläimeksi aktivoivat ominaisuuksia molemmista suunnista, esiintyy joko eläimellisyys tai inhimillisyys voimakkaampana. Luokitteluni tässä kategoriassa tarkastellaan niitä Huovisen eläinkertomuksia, joissa lähtökohta on eläin riippumatta ihmisenkaltaistamisen asteesta.

Kiinnitin edellä huomiota siihen, että allegorinen lukutapa on Huovisen eläinteksteissä mahdollinen mutta ne eivät yhtäaikaisen eläinhuomionsa vuoksi suoraan sovi yksinomaan ihmismaailman asioista puhuvan faabelin määritelmään. Eläinyhteisön kanssakäymistä tarkasteleva "Paneelikeskustelu navetassa" (Lyhyet erikoiset, 1967) käy tästä esimerkiksi: yhtäältä siinä parodioidaan ihmismaailman yksinomaan inhimillisiä käytänteitä - puhe-esityksiin ja argumentaatioon liittyvät puolet - ja toisaalta siinä puidaan kotieläinten hyvinvointiin ja siten ihmisten ja eläinten välisiin suhteisiin liittyviä kysymyksiä ikään kuin eläinten näkökulmasta (1967, I56-163). Lähimpänä faabelin yksitulkintaisuutta Huovinen on sarjassaan "Lintuja elämänmuutoksen edessä" (Ronttosaurus, 1976), joka etenee antropomorfisten mutta ympäristötietoisten lintuesitysten - "Palokärki ja migreeni” ja "Merikotkat tienhaarassa" - kautta kohti ohuempaa faabelia, jossa eksoottisempi "turhautunut kookaburra" vertautuu

ten kaunokirjallisen esittämisen ymmärtämiseen, ja siksi Hermanin ajatusten esittely on luokitteluni kannalta olennainen.

${ }^{10}$ Tarkoitan tässä - samoin kuin jatkossa - inhimillisillä ominaisuuksilla, käytänteillä ja käytöksellä ihmiselle ominaisia, yleensä korkeampia kogniitivisia kykyjä edellyttäviä piirteitä ja toimintaa nojaten yleisiin kulttuurisiin käsityksiin, jotka toisaalta ovat työstettävinä Huovisen kertomuksissa. 
ihmisyhteisöjen toisinajattelijoihin (|6|-|7|). Mikään ei anna ymmärtää, ettei se käsittelisi juuri ihmisten asiaa, mikä on Simonsin (2002, I19) mukaan faabelin piirre. Inhimillisiä ominaisuuksia saavat niin ikään made ja korppikotka ihmiseen keskittyvissä kertomuksissa "Matikanopettaja" (Matikanopettaja, 1986) ja "Hanhikorppikotka" (Rasvamaksa, 1973). Niissä korkeampia kognitiivisia kykyjä omaavat eläimet - shakkia pelaava petolintu ja matematiikkaa ja saksaa opiskeleva made - toimivat välineinä sosioekonomisen ahdingon ja inhimillisen yksinäisyyden kuvauksissa.

Huovisen tuotannon eläinkäsittelyn monipuolisuutta ilmaisee eläin-ihminen-jaottelun laventaminen tavanomaisen tuolle puolen. Kertomuksessa "Ronttosaurus" (1976) muinainen liskoeläinlaji muuntuu pikkuhiljaa mässäilevien tapojensa ansiosta yhä ihmisenkaltaisemmaksi: todellisten liskojen kasvisyönnin muuttuessa kertomuksessa (ongelma)jätteiden syönniksi myös ympäristöhuolen aihe osin naurunalaisine puolineen aktivoituu. Aihepiiriin liittyvänä variaationa mainittakoon poliittinen satiiri Lentsu (1978), joka myös Tero Liukkosen mukaan hyödyntää Huovisen harrastusta faabeleihin (1997, 135) ja jossa "eläin" - yhdenlainen biologinen järjestelmä - on puolestaan flunssavirus, jonka leviämisen myötä kerronnan näkökulma saa syyn vaihtua ikään kuin sattuman valitsemana. Personifioitu virus elää levottomuuden ja kotiutumisen sykliä ja toimii myös konkreettisena transformaation aikaansaajana muuttaessaan isäntänsä terveestä sairaaksi ja luoden näin myös pohjan kerronnalliselle ärhäkkyydelle. Viruksen ihmisenkaltaistamisesta huolimatta sen toiminnan sattumanvaraisuus ja ikään kuin näkymätön konteksti asettavat niin tarinamaailman kuin todellisenkin maailman inhimilliset edesottamukset uusiin ei-ihmiskeskeisiin mittasuhteisiin. Samaan lopputulokseen päädytään Puukansan tarinassa (1984, = PT), jossa ei eläydytä ainoastaan nisäkkäisiin, lintuihin ja hyönteisiin, vaan kokonaisen puuston kohtaloon. Metsä näyttäytyy teoksessa eläimen kaltaisena organismina, jonka ”jättiläismäinen turkki” aaltoilee ja loimahtelee (PT, 58). Puut myös kuvataan "olennoiksi”, eläinmaailmasta vertailukohtia hakien: "Metsän puut olivat suuria elollisia olentoja. Ne olivat jättiläisiä ihmisiin verrattuna, isompia kuin norsut ja valaat." (PT, 18.) Eläinkysymyksen kannalta Puukansan tarina on poikkeuksellinen sen ihmisvähyyden ja siten ei-ihmiskeskeisyyden vuoksi. Kertomuksen alkusysäyksen antaa metsäpalon sytyttävä anonyymi mies. Seuraavan kerran ihminen kohdataan palomaalla puolen vuosisadan päästä ja lopulta 1920-luvulla metsänhoitajan ominaisuudessa. IImentymää, jossa luonto saa eläimen muodon, voi pitää tässä käsitellyn kategorian alalajina tai variaationa.

\section{Ihminen saa eläimen ominaisuuksia}

John Simons toteaa, että mitä lähemmäs ei-inhimillistä eli eläintä fiktiivisessä maailmassa pyritään, sitä enemmän representoinnin strategiat koettelevat ihmisen ja eläimen rajoja. Parhaimmassa tapauksessa näin on myös mahdollisuus päästä jollain tavoin jyvälle eläimen kokemuksen esittämisestä. (Simons 2002, 140.) Sama käsitys näyttäisi jäsentävän myös Hermanin jatkumoa. Kaunokirjallisuudessa kautta aikain hyödynnetty 
muodonmuutoksen strategia on eläimen ja ihmisen rajojen hälventämisen kyvyssään erityinen, ja kuten Simons osoittaa, se mahdollistaa monenlaisia toteutuksia ja siten myös ilmaisee eri astein ja asetelmin ihmisen ja eläimen kaltaisuuksia ja eroja. Transformaatiokertomuksissa keskeisiä kysymyksiä ihmisen ja eläimen välisen suhteen ilmaisemisessa on ensinnäkin se, miten eläimen ja ihmisen kategoriat näyttäytyvät suhteessa toisiinsa arvottavassa mielessä, ja toiseksi se, korostuvatko ihmisten ja eläinten väliset kaltaisuudet vai eroavaisuudet. Samoin huomioitavaa on siinä, minkä asteisena transformaatio tapahtuu ja miten inhimillinen tietoisuus säilyy tai muuntuu sen myötä.

Yksi Simonsin keskeinen transformaatiokertomusten jaottelu pohjautuu siihen, koetaanko kertomuksessa fyysinen muodonmuutos vai onko kyseessä ei-inhimillisen eläimen asemaan asettuminen ihmismaailmassa. Juuri konkreettisen muodonmuutoksen läpikäyminen edustaa kaunokirjallisuuden perinteisiä asetelmia antiikista alkaen. Huovisen tuotannossa puhtain variaatio siitä saa ilmaisunsa lyhytkertomuksessa "Sielunvaellusta" (Rasvamaksa, 1973)," jossa Leevi Sytky -niminen mies saa tapaturmaisen kuolemansa jälkeen tilaisuuden "yrittää sielunvaellusta". Hän vierailee variksen, mateen, koiran, Alkon paikallisjohtajan ja kurjen olomuodossa. Kuten Odysseian kymmenennessä laulussa, jossa Kirke muuttaa Odysseuksen miehet sioiksi, tai Apuleiuksen Kultainen aasi -romaanissa, myös Huovisen muodonmuutoksia kokeva taho säilyttää inhimillisen tietoisuutensa, toisin kuin esimerkiksi Kafkan Muodonmuutoksessa, jossa myös Gregor Samsan tietoisuus kokee muutoksen hyönteismäiseen suuntaan. Huovisen kertomuksessa Sytkyn sukupuoli pysyy - vähintään viimeiseen vaihdokseen asti - samana ja hänen turmakseen koitunut, inhimillisen ilmaisun saava mielenkiinto vastakkaista sukupuolta kohtaan näyttäytyy myös mateen olomuodossa (s. 132, 137).

Inhimillisen tietoisuuden säilyminen eläinmuodossa ilmaisee arvoasetelmaa ihmisen ja eläimen välillä: juuri inhimillinen tietoisuus vierailtujen elämänmuotojen suhteesta johonkin ihmisten arvostamaan saa Sytkyn vaihtamaan maisemaa ja sielua kerta toisensa jälkeen. Ennen Huovisen tuotannossa tyypillisen pakomotiivin täyttymistä - Sytky lähtee lopussa kurkena Lappiin - Sytky vierailee Alkon paikallisjohtajan olemuksessa ja huuhtoo koiran ja mateen ("matikan") maun suustaan (s. I4I). Fyysisestä transformaatiostaan huolimatta Sytky sinänsä tai Sytky eläimen sisällä ei siis muutu, vaikka omaksuukin kunkin eläimen käytöstavat niiden aistien ohjaamana. Tässä mielessä ilmaistu suhde eläimeen on hyödyntävä ja eläinolomuoto ihmiseen nähden alisteinen.

Muodonmuutos on kuitenkin myös satiirinen ja humoristinen trooppi, ja sellaisena se myös Huovisen kertomuksessa näyttäytyy. Kokonaisuutena kertomus asettaa ihmiskeskeisen maailmantulkinnan naurettavaan valoon. Jo lähtöasetelma puhuu sen puolesta, sillä Sytky joutuu kuoltuaan kristinuskon asetelmia parodioivaan tilanteeseen eli sata metriä pitkän, riukuvarsisaappaisen ja ison kirjoituspöydän takana istuvan

1 Arto Seppälä on kiinnittänyt huomiota "Sielunvaellusta"-kertomuksen ja Lentsun väliseen kaltaisuuteen mitä ilmeisemmin juuri muodonmuutosaiheeseen liittyen (1992, 183). 
Jumalan juttusille; yhdessä he punnitsevat Sytkyn kuolemanjälkeisiä vaihtoehtoja (s. 132).

Erisuuntaiset transformaatiokertomukset muodostavat leijonanosan Huovisen eläinaiheisista kertomuksista. Jos transformaation käsitettä laajennetaan Simonsin (2002, 167-169) tapaan fyysisestä henkiseen transformaatioon, lähestulkoon kaikki Huovisen eläinaiheiset tekstit voidaan lukea kategoriaan. Tällaisen transformaation lähde on Simonsin esimerkeissä eläimen ihmiseen synnyttämän tunnesiteen aiheuttama henkinen muutos. Simons esittää, että eläimet herättävät ihmisessä rakkautta ja voivat siten muuttaa ihmistä sisäisesti. Huovisen osalta tällainen transformaatio käynnistyy romaanissa Koirankynnen leikkaaja (1980), jossa Sakke-koiran ja päähenkilö Mertsin välille luodaan jo alkuasetelmassa henkinen yhteys ja jossa Mertsin myötätunto eläintä kohtaan asettuu analogiseen asetelmaan ihmistenvälisen kanssakäymisen kanssa.

Huovisen eläintekstiluokan "ihminen saa eläimen ominaisuuksia" muodonmuutoskuvauksia ovatkin kertomukset, joissa fyysistä transformaatiota ei varsinaisesti tapahdu mutta joissa asetutaan eläimen asemaan. Myös Simons kiinnittää esimerkeissään huomiota tämänkaltaiseen muuttumiseen. ${ }^{12}$ Oman alalukunsa näille transformaation ilmentymille muodostavat Huovisen tuotannossa syömiseen kytkeytyvät tekstit, ${ }^{13}$ lyhyet erikoiset "Kasvissyöntikausi" (= K, teoksessa Ympäristöministeri, 1982) sekä "Rasvamaksa" ja "Pystyynmarinoitu nainen" (Rasvamaksa, 1973), jotka yhdessä muodostavat kokonaisuuden "Ihmissyöntiä I-II". ${ }^{4}$ Luonnonmukaisuuden etsijöitä irvailevan "Kasvissyöntikauden" - jonka Tero Liukkonen luokittelee faabeliksi (1997, 130) - alkuasetelma on se, että miesparivaljakko lähtee metsään tavoitteenaan puhdistautua henkisesti ja fyysisesti. Ennen pitkää he alkavat saada eläimellisiä, metsäkanalinnun piirteitä: he syövät havunneulasia, kiipeävät pylväskengillä puun latvaan ja yöpyvät hyyvöskuopissa. Heidän ulosteensa muuttuvat "metsomaisiksi pökäleiksi” (K, I43-I45). Talven kääntyessä kevääksi miehet palaavat takaisin ihmisten pariin mukavuudenhalun ja inhimillisen levottomuuden ajamana. Miehet kohtaavat metsässä myös eläimiä, joita hybridit hämmentävät; vanha metso erehtyy pitämään miehiä kilpakosijoina (K, 147). Miesten ulkomuoto on niin ikään muuttunut ravinnon johdosta yhä ruokkoamattomampaan ja siten myös eläimellisempään suuntaan: "Vihreä vaahto valuu pitkin suupieliä ja värjää parran. Hampaat

${ }^{12}$ Simons käsittelee transformaatioluvussaan mm. David Garnettin romaania A Man in the Zoo (1924), jossa John Cromartie -niminen mies suostuu vapaaehtoisesti esille eläintarhaan ihmisapinoiden rinnalle (Simons 2002, I50-152). Ihmisen esiintyminen eläimenä muodostaa näin yhden transformaatioluokan.

${ }^{13}$ Nämä kertomukset eivät ole perinteisiä faabeleita, mutta asetelmaltaan varsinkin eläineettisestä näkökulmasta tässä kiinnostavia: kahdessa niistä ihmiset valmistetaan ruuaksi eläimen tavoin ja on mahdollista, että ne herättävät lukijassaan ajatuksia lihansyönnistä myös laajemmin - oli kirjailijan intentio sitten mikä tahansa.

${ }^{14}$ Eläimiin liittyvän asetelman esiinnostaminen ei tässä merkitse kertomusten satiirisen luonteen kiistämistä: "Ihmissyöntiä I-II" irvailevat tunnetusti kehitysavun kustannuksella (ks. esim. Rajala 2012, 195; Seppälä 1992, 2 I4 ja Riikonen 2012, 340-34I). Sen sijaan tässä esille tuomani (karnevalistiset) asetelmat palvelevat satiirin tavoitteita, ja tätä puolta tulisi tarkastella omana kokonaisuutenaan erillisessä artikkelissa. 
muuttuvat vihreiksi kuin vanhalla hevosella.” (K, I46.) Näin ollen transformaatio on ulkokohtainen, olkoonkin, että toiveena ollut puhdistautuminen - yhdenlainen muutos - toteutuu. Näennäisestä eläimenkaltaistumisen toteutumisesta huolimatta teksti on omiaan korostamaan ihmisen ja eläimen välistä eroa, sillä se nostaa ihmiskategorian eläimen yläpuolelle osittain pilanteon siivittämänä. Näin käy myös kertomuksissa "Nudistit retkellä" ja "Ostjakki ja Voguli” (Lyhyet erikoiset, 1967), joissa kummassakin operoidaan ihmiskategorian sisällä olevien etäännytysten kautta. Samalla myös ihmisen ja eläimen välisten erojen luonne korostuu luonnon näyttäytyessä yhtäältä kulttuurin ulkopuolisena alueena ja toisaalta eläinten luonnollisena elinympäristönä inhimillisine kuokkavieraineen.

Kertomukset "Rasvamaksa" ja "Pystyynmarinoitu nainen" näyttäytyvät eläinasetelmana omalaatuisen kulinarisminsa myötä. Niissä vuoroin mies ("Rasvamaksa") ja nainen ("Pystyyn marinoitu nainen") joutuu ihmisravinnoksi periaatteessa eläimen tapaan: eläimen ja ihmisen välistä asetelmaa vastaa epäkorrekti erottelu afrikkalaisen ja suomalaisen välillä. Se on lähellä Jonathan Swiftin satiirisen pamfletin A Modest Proposal (I729) asetelmaa, jossa suositellaan kannibalismia nälänhädän torjumiseen. Simons näkee Swiftin teoksen käänteisenä "vahvan antropomorfismin" ilmentäjänä, jossa eläin-ihmisasetelmaa vastaa erottelu köyhän ja rikkaan välillä (2002, 125). Huovisen kertomuksissa asetelma on sikäli erilainen, että syödyksi joutuu kohdeyleisön kaltainen (valkoihoinen) ihminen, kun taas syöjä on - kummassakin kertomuksessa vauras ja sivistynyt - afrikkalainen, mikä puolestaan palvelee kertomuksen satiirisia pyrkimyksiä. Huovisen romaaneissa Hamsterit (1957) ja Lemmikkieläin (1966) "eläimellistyminen" liittyy niin ikään asetelmaan, mutta hienovaraisemmalla tavalla, sillä niissä päähenkilöt käyttäytyvät eläimen tavoin oman valintansa tuloksena ja tietynlaisena performanssina: varustautuessaan eläimen tavoin talven varalle tai ryhtyessään lemmikkieläimeksi motiivinaan taloudellinen hyöty. Tämänkaltaiset kertomukset pohjautuvat kaltaisuudelle, mutta ne tulevat korostaneeksi eläinten ja ihmisten välisiä eroja. Jos ihminen on näissä kertomuksissa alisteisessa asemassa, kuten romaanissa Lemmikkieläin, aktivoituvat myös eläinten asemaan liittyvät eettiset kysymykset.

Huovinen on etenkin Lampaansyöjät-romaaninsa (1970) ansioista myös tunnettu lihansyönnin kuvaaja. Teosta läpikäyvänä motiivina liha kuolleen eläimen representaatio - on eläinasian kannalta merkityksellinen ilmentymä. Kertomus on kuitenkin tässä esitellyn luokittelun kannalta problemaattinen, sillä vaikka liha on konkreettisesti eläintä, ei se edusta sitä suoraan syöjälleen, vaan on, kuten tutkija Carol J. Adams (2002, $5 \mathrm{I}$ ) on esittänyt, poissaoleva viittauskohde. Tässä mielessä liha merkitsee muuttumista ei-keneksikään niin eläimelle kuin sen syöjälle (mt., 5I-52). Vaikka Huovisen kertomus "Muodonmuutoksia" (= M, Ympäristöministeri, 1982) ei ole eläinteksti sikäli, että siinä kuvataan ihmisen varttumista kehdosta hautaan, on se syytä ottaa tässä yhteydessä esiin, sillä siinä anonyymin, kersantiksi edenneen keskushenkilön tappaa krokotiili, ja myös haaskalinnut pääsevät hänen lihaansa käsiksi ( $M, 94-95)$. Näin kuvataan 
ei-keneksikään muuttuminen, joka on kaiken elävän kohtalo luonnon kiertokulussa.

Aiemmin mainittu Huovisen romaani Koirankynnen leikkaaja (= $\mathrm{KL}$ ) käy esimerkiksi siitä, että eläinten esittämisen strategiat voivat vaihdella myös kokonaisuuden sisällä. Romaanin jännite rakentuu ihmisen ja koiran välille, sillä sen johtomotiivi on sodassa päähän haavoittuneen Mertsi Vepsäläisen auttamismatka kärsivän koiran luo. Päähenkilö Mertsi saa romaanissa eläimen ominaisuuksia siinä mielessä, että hän vertautuu ja häntä verrataan monin tavoin eläimiin: hän on kuin "sairas eläin" tai kuin "pöllö" (KL, I2, I5). Hänen ajatuspuheensa on yksinkertaisuudessaan ja etenkin koiraa käsitellessään "eläimellistä" (ks. esim. $K L, \mid 8,5 I$, 87). Toisaalta Sakke-niminen koira esitetään erityisellä tavalla "koiruuteen" eläytyen (KL, I22). Mertsin ajatuksissa ja häntä käsittelevän kertomuksen myötä eläimen ja ihmisen välinen hierarkia kääntyy Huovisen yhdistäessä Mertsin eläimen pyyteettömyyteen ja "hyvyyteen”. Myös Mertsin omassa näkemyksessä ihmiset ovat eläimistä poiketen "jotenkin pahoja ja raakoja" (KL, 32-33). Mertsin "eläimenkaltaisuus" ja altavastaajan asema tekee hänestä kertomuksessa myös inhimillisen välikappaleen eläimen kokemuksen esilletuojana: omasta kärsivän asemastaan hän ymmärtää eläimen kärsimyksen muita sensitiivisemmin (KL, 27, 87). Koirankynnen leikkaaja onkin Huovisen tuotannossa eläinten asian käsittelyn osalta erityinen, koska siinä hänen teoksilleen tyypillinen miesten välinen ystävyys ja avunanto (Rajala 2012, 225) laajenee miehistä lastenkaltaisten kautta eläimiin eikä siinä hyödynnetä lähtökohtaisesti etäännyttävää humoristista otetta.

\section{Eläin eläimenä tai ihminen eläimen äänitorvena}

Tekstit, joissa otetaan suoraan kantaa eläinten oikeuksien puolesta, muodostavat erityisen, temaattisen kokonaisuuden Veikko Huovisen eläintekstien joukossa. Niiden lähtöasetelma on ihmiskeskeistä maailmankuvaa horjuttava, kuten Huovisen fantastisemmissa eläinteksteissä. ${ }^{15}$ Tämä luokka nojaa "suoraan sanottuun", sillä tulkinnan kautta myös monet muihin luokkiin asettuvista Huovisen eläinteksteistä näyttäytyvät eläinsympaattisina puheenvuoroina. Luokan tekstit lähestyvät asiatekstiä tai hyödyntävät sellaisen asetelmia - tutkielma, haastattelu - Huoviselle tyypilliseen tapaan. Näin syntyvä koominen efekti asettaa paikoin kirjaimellisen lukutavan kyseenalaiseksi, mutta se ei koskaan täysin ohitu.

Huovisen eläinhaastattelujen sarjan - "Karhu", "Sika", ”Jänis", "Kana", "Koe-eläin", "Leijona" (teoksessa Porsaan paperit, $1999=$ PP) läpikäyvä teema on eläinten hyötykäytön kritiikki ja eläinten kulttuuristen representaatioiden kaksinaismoralistinen suhde siihen. Vaikka haastatel-

\footnotetext{
${ }^{15}$ Nojaan tässä Tero Liukkosen havaintoon siitä, että Huovisen tuotanto "voidaan jakaa karkeistaen kahtia sen mukaan, onko kertomuksen maailma perustaltaan fantastinen vai realistinen", toisin sanoen kyse on "mielikuvituksellisen sepitteen" ja realistisen kerronnan välisestä eronteosta, ei yliluonnollisia ilmiöitä kuvaavasta fantasiakirjallisuudesta $(1997,65)$.
} 
lut, puhuvat eläimet näyttäytyvät inhimillistettyinä, ei asetelma ole yksinkertainen. Eläimet toimivat kertomuksissa näkökulmina toislajisen tilaan, ja kertojana toimivan haastattelijan tehtävä on tulkinnallinen: tohtori Dolittlen tapaan hän ymmärtää eläinten puhetta sen sijaan että nämä puhuisivat ihmiskieltä. Haastattelija tosin kiinnittää erityistä huomiota omaan eläimille suunnattuun puheeseensa ( $\mathrm{PP}, 10,17,34)$, ja etäisyys kahden toisilleen vieraan välilä korostuu myös teitittelyn ja passiivin käytön vuoksi. Haastatteluista esiin käyvä ei-romantisoitu eläintodellisuus asettuu räikeään vastakohtaan niissä niin ikään esille tulevien eläinten kulttuuristen representaatioiden kanssa (PP, 20, 24, 30). Tässä mielessä ne ovat oikaisevalla tavalla "eläinten asialla". Kokoelman tekstit "Koe-eläin" ja "Ihminen ja eläin" (teoksessa Kuikka, 1963) tarttuvat suorasanaisimmin eläinoikeudellisiin kysymyksiin ja käsittelevät pohjimmiltaan ihmisen epäeettistä toimintaa.

Kertomus "Isku yössä" (= IY, teoksessa Ronttosaurus, 1976) asettuu tässä käsiteltyjen luokkien välimaastoon, sillä eläinoikeuslähtökohdastaan ja tulkinnallisesta lopputuloksestaan huolimatta se kuvaa myös eläimiä eläiminä ja mikä kiinnostavinta, myös ihmistä samassa elämän, kuoleman (ja tappamisen) kiertokulussa kuin eläintä. Samalla se on kirjallisuutemme traditiossa poikkeuksellinen eläinten vapautusrintama -henkisen toiminnan kuvauksessaan. Toiminnan alkuunpanijana toimii Helsinkiin kertomuksen alussa saapuva "noin 40-vuotias pitkä, harteikas mies" (IY, I39), jonka toteutuvana pyrkimyksenä on vapauttaa Korkeasaaren eläintarhan eläimiä. Kertomuksessa seurataan omissa luvuissaan isojen, Suomen luontoon kuuluvien eläinten (ilves, hirvipari, seitsemän sutta) selviytymistä vapaudessa ilman yksilöityä ihmisvaikutusta. On huomionarvoista, että tietyt eläimet vapautettuaan kertomuksen primus motor murtautuu vesilintujen suojiin ja vääntää niskat nurin kanadanhanhelta syödäkseen sen myöhemmin (IY, I42).

Eläimet kuitenkin esitetään päinvastaisella tavalla eläiminä Ympäristöministerin (1982) kertomuksessa "Kaksi lisääntymiskertomusta" (= KLK), jossa Ossi Vatanen -nimisen miehen eläinrakkaus saa luonnon tasapainon järkkymään. Ensin hänen omistamansa saari on varisten valloittama, sitten kissojen. Siinä missä eläimet näyttäytyvät eläiminä vietteineen, muuttuu Vatanen heidän seurassaan pseudoeläimeksi: hän pukeutuu varikseksi, ompelee variksenharmaaseen puseroonsa mustan paikan ja takahelmaan siipiä muistuttavat hännykset ja opettelee raivokkaan raakuntatyylin toimiakseen lauman "isovariksena" ja johtajana megafoni apunaan (KLK, 35-37). Myöhemmin hän myös puhelee kissoille näiden kielellä: "Miau, kurnau, sanoi Ossi kimakimmalla äänellään ja kutitti kissoja leuan alta" (KLK, 4I). Vatasen "muodonmuutos" on omiaan korostamaan eroa ihmisen ja eläimen välillä, ja hänen liioiteltu sentimentaalisuutensa toimii etäännyttävän komiikan lähteenä.

Huovisen eläintekstit antavat aiheen puhua eläytyvästä menetelmästä (vrt. Rajala 2012, I59). Sitä hyödynnettäessä niin etäisyys ihmisestä kuin kaltaisuus ihmisen kanssa korostuvat ja eläin tulee kuvatuksi eläimenä, sen oletetusta kokemuksesta käsin. Menetelmää sovelletaan fantastisissa kertomuksissa ihmisyhteyden kautta, mutta myös niissä eläimiä 
toimijoina hyödyntävissä teksteissä, joiden kehys on muilta osin realistinen. Koiran näkökulma vahvistuu Koirankynnen leikkaajan loppupuolella, sillä siinä viivähdetään paikoin Sakke-koiran "ajatuspuheessa": "Koiralla oli ikävä isäntäänsä. Sen silmissä viipyi alakuloinen, kaipaava katse. Missä se Ville on. Mihin se on mennyt. Miksi Ville ei ole enää koskaan kotona. Miksi se ei ota häntä mukaansa." (KL, I22.) Koiran ajatuspuhe on muodoltaan yksinkertaista ja toistavaa, samanlaista kuin Mertsin. Tällä tavalla myös yhteys Mertsiin vahvistuu kertomuksen hierarkiassa. Kertoja osoittaa lisäksi koiran viestivän saman elein ja äännähdyksin: "Koira nosti kuononsa ylös ja valitti” (KL, I22). Vaikka onkin selvää, ettei yksikään ihminen pysty ymmärtämään eläintä niin syvällisesti, että voisi toimia sen kokemuksen toisintajana (vrt. Simons 2002, 86), on siihen eläytymisessä kuitenkin aste-eroja. ${ }^{16} \mathrm{Se}$ että ylipäätään voimme kuvitella ei-inhimillisen kokemuksen ja suhtautua siihen myötäeläen vertaamalla sitä omaamme, antaa meille kyvyn esittää se (mp.).

Huovisen koiratekstien valikoimassa Kylän koirat (1962, = KK) päästään osittain sen kuvasisällön ansiosta sellaiseen hienosyiseen eläimen kokemuksen kuvaukseen, jota Herman nähdäkseni ajaa takaa puhuessaan elinympäristöön osallistumisesta. Teoksessa on läpikulkeva tarkkailuasetelma, jossa kirjailijan oloinen mies tekee selkoa koiran olemuksesta jaetun elinpiirin (todellisten) tapahtumien pohjalta. ${ }^{17}$ Kaikkien tekstien tapahtumapaikka on kirjailijan kotipaikka, Sotkamon kirkonkylä. Teoksessa on kaksikymmentäneljä koiravalokuvaa kuvateksteineen. Osassa niistä tulkitaan koiran asentoja ja eleitä ihmiskielelle (ks. esim. seuraavan sivun kuva, KK, 83). Kuvien ja kertomuksen yhdistelmä auttaa kuvittelemaan koirien kokemuksen suhteessa yhteiseen mutta eri tavalla koettuun elinpiiriimme. Myös koiramaailman asioista puhuttaessa kertoja asettuu koiran asemaan pyrkien kiinnittämään huomiota sen ihmisestä eroaviin aistikokemuksiin, etenkin hajuaistimuksiin. Se käy ilmi jo valikoiman avauksessa, jonka lopussa kertoja ilmaisee riisuvansa ihmisnaamionsa ja antavansa korvien "valua poskille" ja nokan "kostua hyvävainuiseksi" (KK, 17). Tässä mielessä Hermanin jaottelun hienosyisin muoto toteuttaa yhdeltä osin eläintä eläimenä kuvaavaa kategoriaa, jota Simons ei puolestaan erikseen nimeä.

\footnotetext{
${ }^{16}$ Toisaalta erilaiset tekniset innovaatiot tarjonnevat tulevaisuudessa myös kirjallisuuden käyttöön uutta tietoa eläinten ajatuksista, vrt. The Nordic Society for Invention and Discovery -tutkimusryhmän kehittämä, koirien ajatuksia tulkitseva ja kielellistävä "No more woof" -laite, ks. http://www.hs.fi/tiede/al 390480050025 ja http://www.nordicinvention.com/.

${ }^{17}$ Panu Rajalan tapaan - ja toisin kuin Tero Liukkonen - pidän Kylän koirat -kokoelmaa ensisijaisesti koiralauman käyttäytymisen kuvauksena (Rajala 2012, 160 ja Liukkonen 1997, 57-58).
} 


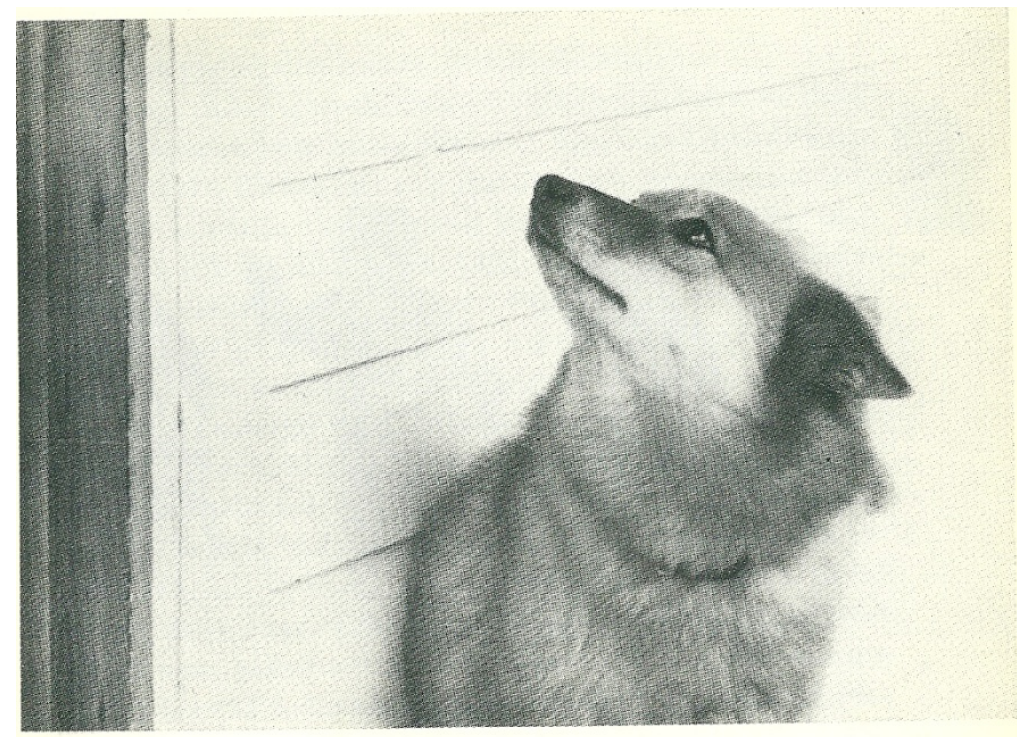

Eikö nyt kukaan kuule! Pitäisi ehdottomasti päästä sisälle lämmittelemään.

Huovisen Kylän koirien kuvitusta (KK, 83).

\section{Lopuksi}

Olen artikkelissani luonut Veikko Huovisen eläintekstien luokittelun ja suhteuttanut sitä olemassa oleviin eläinkertomusten tai eläimen kokemuksen kaunokirjallisen esittämisen luokitteluihin. Sen pohjalta olen osoittanut Huovisen kuvanneen eläinkuntaa ja eläimiin liittyviä asetelmia poikkeuksellisen monipuolisesti, realistisen ja fantastisen elementin eriasteisin painotuksin. Toisaalta on käynyt ilmi, etteivät olemassa olevat luokittelut täysin vastaa Huovisen tuotannosta kumpuavaa eläimen tai "eläimellisen" monipuolista representointia. Luokitteluihin usein liittyvä ongelma näyttäytyy myös Huovisen eläintekstien luokittelussa osittaisina päällekkäisyyksinä. Samoin kirjallisuuteen aina liittyvä tulkinta ohjaa viime kädessä kunkin tekstin sijoittumista eri kategorioihin - näin käy myös tulkittaessa tekstejä suhteessa aiempiin luokitteluihin, varsinkin silloin, jos niissä esitetyt luokat ovat laveita eivätkä välttämättä lähtökohtaisesti edes poissulkeviksi tarkoitettuja, kuten esimerkiksi Simonsin tapauksessa.

Laatimani kirjailijakohtainen eläinaiheen käsittelyn luokittelu toi esiin aiempiin nähden uuden luokan vaateen eli sellaisten tekstien temaattisen kategorian, joissa suoraan käsitellään eläinten oikeuksiin liittyviä kysymyksiä. Tämä luokka pitää sisällään ei-fiktiiviset tai sellaista jäljittelevät tekstit, samoin kuin se asettaa Huovisen eläinallegorioiksi usein luetut tekstit uuteen valoon: eläinten oikeuksia eksplisiittisesti sivuavat tekstit huventavat allegorisen tulkinnan tarkoituksenmukaisuutta myös Huovisen muun tuotannon yhteydessä. Toin niin ikään esille, että Huovinen tavoittaa eläimen kokemuksen kaunokirjallisen esittämisen 
hienosyisimmän muodon kuvatessaan koiria teoksissa Kylän koirat ja Koirankynnen leikkaaja. Eläinasian laajamittainen luotaaminen osoitti, että Huovisen eläintekstit kyseenalaistavat kokonaisuutena antroposentrisen maailmankuvan ihmisten, eläinten, eliöiden ja kasvien etualaistamisen varioinnillaan. Huovisen eläinaiheiset teokset kertovat voittopuolisesti tekijän myötämielisestä suhtautumisesta eläimiin ja käsittelevät niiden vaikeaa osaa keskuudessamme, ihmisen ja eläimen välistä eroa loitointaen ja lähentäen.

\section{LIITE: Veikko Huovisen eläintekstien lajittelu}

Luokat:

$\mathrm{IE}=$ ihminen eläinten asialla $\quad \mathrm{IEO}=$ ihminen saa eläinten ominaisuuksia

$\mathrm{EIO}=$ eläin saa ihmisen ominaisuuksia $\quad \mathrm{EE}=$ eläin eläimenä

\begin{tabular}{|c|c|c|c|c|}
\hline nimi & julkaisuvuosi & laji & eläin & kategoria \\
\hline Eläinten tervehdys ihmisille & 1999 & liite & eläinluettelo & $\mathrm{IE}, \mathrm{EIO}$ \\
\hline Erotuomari & 1986 & lyhytproosa & ihminen & IEO \\
\hline Hanhikorppikotka & 1973 & lyhytproosa & korppikotka & $\mathrm{EIO}$ \\
\hline $\begin{array}{l}\text { Innostunut Sonni ja Saippuakauppi- } \\
\text { as }\end{array}$ & 1986 & lyhytproosa & sonni & $\mathrm{EIO}$ \\
\hline Hamsterit & 1957 & romaani & ihminen & IEO \\
\hline Ihminen ja eläin & 1963 (1959) & essee / artikkeli & ihminen & IE \\
\hline Isku yössä & 1976 & lyhytproosa & ihminen, ilves, hirvi, susi & IE, EE \\
\hline Kaksi lisääntymiskertomusta & 1982 & lyhytproosa & varis, kissa, ihminen & IEO, EE \\
\hline Kana & 1999 & lyhytproosa & ihminen ja kana & $\mathrm{IE}, \mathrm{EIO}$ \\
\hline Karhu & 1999 & lyhytproosa & ihminen ja karhu & $\mathrm{IE}, \mathrm{EIO}$ \\
\hline Kasvissyöntikausi & 1982 & lyhytproosa & ihminen & IEO \\
\hline Koe-eläin & 1999 & lyhytproosa & ihminen ja rotta & $\mathrm{IE}, \mathrm{EIO}$ \\
\hline Koirankynnen leikkaaja & 1980 & romaani & ihminen, koira & IEO, EE \\
\hline Kuikka & 1963 & lyhytproosa & kuikka & EIO \\
\hline Kylän koirat & 1962 & proosa & koira & EE, IEO \\
\hline Lampaansyöjät & 1970 & romaani & lammas & EE \\
\hline Leijona & 1999 & lyhytproosa & ihminen ja leijona & $\mathrm{IE}, \mathrm{EIO}$ \\
\hline Lemmikkieläin & 1966 & romaani & ihminen & IEO \\
\hline Lentsu & 1978 & romaani & virus & $\mathrm{EIO}$ \\
\hline Lintuja elämänmuutoksen edessä & 1976 & lyhytproosa & $\begin{array}{l}\text { palokärki, merikotka, kookabur- } \\
\text { ra }\end{array}$ & $\mathrm{EIO}$ \\
\hline Matikanopettaja & 1986 & lyhytproosa & ihminen ja made & $\mathrm{EIO}$ \\
\hline Nudistit retkellä & 1967 & lyhytproosa & ihminen & IEO \\
\hline Ostjakki ja voguli & 1967 & lyhytproosa & ihminen & IEO \\
\hline Paneelikeskustelu navetassa & 1967 & lyhytproosa & kana, pässi, lehmä, sika & $\mathrm{EIO}$ \\
\hline Puukansan tarina & 1984 & $\begin{array}{l}\text { romaani / tietote- } \\
\text { os }\end{array}$ & metsä & LEO \\
\hline Pystyynmarinoitu nainen & 1973 & lyhytproosa & ihminen & IEO \\
\hline Rasvamaksa & 1973 & lyhytproosa & ihminen & IEO \\
\hline Ronttosaurus & 1976 & lyhytproosa & hirmulisko & $\mathrm{EIO}$ \\
\hline Sielunvaellusta & 1973 & lyhytproosa & $\begin{array}{l}\text { varis, koira, made, ihminen, } \\
\text { kurki }\end{array}$ & IEO, EIO \\
\hline Sika & 1999 & lyhytproosa & ihminen ja sika & IE, EIO \\
\hline Tarzan ja Suomi & 1967 & lyhytproosa & ihminen & IEO \\
\hline
\end{tabular}




\section{LÄHTEET}

\section{Kaunokirjallinen aineisto}

Huovinen, Veikko 1957: Hamsterit. Helsinki: WSOY.

Huovinen, Veikko 1980/1962: Kylän koirat. Helsinki: WSOY. (= KK)

Huovinen, Veikko 1963: Kuikka. Helsinki: WSOY.

Huovinen, Veikko 1966: Lemmikkieläin. Fantasia ihmisistäni. Helsinki: WSOY.

Huovinen, Veikko 1967: Lyhyet erikoiset. Helsinki: WSOY.

Huovinen, Veikko 1970: Lampaansyöjät. Helsinki: WSOY.

Huovinen, Veikko 1973: Rasvamaksa. Helsinki: WSOY.

Huovinen, Veikko 1976: Ronttosaurus. Helsinki: Otava.

Huovinen, Veikko 1978: Lentsu. Helsinki: Otava.

Huovinen, Veikko 1980: Koirankynnen leikkaaja. Helsinki: Otava. (= KL)

Huovinen, Veikko I 982: Ympäristöministeri. Helsinki: Otava.

Huovinen, Veikko 1984: Puukansan tarina. Kuvittanut Seppo Polameri. Helsinki: Otava. (= PT)

Huovinen, Veikko 1986: Matikanopettaja. Littlejuttuja eri aihelmista. Helsinki: Otava.

Huovinen, Veikko 1999: Porsaan paperit. Helsinki: WSOY. (= PP)

\section{Muut lähteet}

Aaltola, Elisa 2012: Johdanto: Ihminen, eläin vai molemmat? Johdatus eläinfilosofiaan. Toim. Elisa Aaltola. Helsinki: Gaudeamus, 9-27.

Adams, Carol J. 2002/1990: The Sexual Politics of Meat. A FeministVegetarian Critical Theory. New York: Continuum.

Garrard, Greg 2012: Ecocriticism. Second edition. London \& New York: Routledge.

Harel, Naama 2009: The Animal Voice Behind the Animal Fable. Journal for Critical Animal Studies (2:2009), 8-20.

Herman, David 2012: Toward a Zoonarratology: Storytelling and Species Difference in Animal Comics. M. Lehtimäki, L. Karttunen \& M. Mäkelä (eds.), Narrative, Interrupted. The Plotless, the Disturbing and the Trivial in Literature. Berlin and Boston: De Gruyter, 93II9.

Huovinen, Veikko 200I: Muina miehinä. Kirjailijan muistelmia. Helsinki: WSOY. 
Kantola, Janna 2013: Hanhikorppikotkia ja ronttosauruksia: eläinten osa Veikko Huovisen tuotannossa. Kiviaholinna: suomalainen romaani. Toim. Vesa Haapala ja Juhani Sipilä. Helsinki: Avain, 225-24I.

Lahtinen, Toni 2008: Eko, heko. Saako ympäristöhuolelle nauraa? Ekokarnevaali Veikko Huovisen Ympäristöministerissä. Äänekäs kevät. Ekokriittinen kirjallisuudentutkimus. Toim. Toni Lahtinen ja Markku Lehtimäki. Helsinki: Suomalaisen Kirjallisuuden Seura, 30-49.

Liukkonen, Tero 1997: Veikko Huovinen. Kertoja, veitikka, toisinajattelija. Helsinki: SKS.

Nykysuomen sanakirja 1996. Osa IV: O-R. Neljästoista painos. Helsinki: WSOY.

Rajala, Panu 2012: Hirmuinen humoristi. Veikko Huovisen satiirit ja savotat. Helsinki: WSOY.

Riikonen, Hannu 2012: Huumorin ja satiirin rajamailla: Veikko Huovinen ja Arto Paasilinna. Satiiri Suomessa. Toim. Sari Kivistö ja Hannu Riikonen. Helsinki: SKS.

Seppälä, Arto 1992: Ajatus on hiirihaukka. Veikko Huovinen, humoristi. Helsinki: WSOY.

Simons, John 2002: Animal Rights and the Politics of Literary Representation. London \& New York: Palgrave.

Uexküll, Jacob von 1909: Umwelt und Innenwelt der Tiere. Berlin: Verlag von Julius Springer.

https://openlibrary.org/books/OL2335260IM/Umwelt_und_Innen welt_der_Tiere (viitattu 20.1 I.20I3).

\section{Kirjoittaja}

Janna Kantola, FT, dosentti, yliopistonlehtori, Helsingin yliopisto,

yleinen kirjallisuustiede (janna.kantola[at]helsinki.fi)

Joutsen / Svanen 20I4. ISSN 2342-2459

www.helsinki.fi/kirjallisuuspankki/joutsen-svanen-2014 